\title{
Role of Clinical Presentations and Routine CSF Analysis in the Rapid Diagnosis of Acute Bacterial Meningitis in Cases of Negative Gram Stained Smears
}

\author{
Rabab Fouad, ${ }^{1}$ Marwa Khairy, ${ }^{1}$ Waleed Fathalah, ${ }^{1}$ Taha Gad, ${ }^{2}$ \\ Badawy El-Kholy, ${ }^{3}$ and Ayman Yosry ${ }^{1}$ \\ ${ }^{1}$ Endemic Medicine Department and Hepatology Unit, Faculty of Medicine, Cairo University, Cairo 11562, Egypt \\ ${ }^{2}$ Shebin El-Kom Fever Hospital, Egyptian Ministry of Health, Menoufia 12489, Egypt \\ ${ }^{3}$ Clinical Pathology Department, Faculty of Medicine, Cairo University, Cairo 11562, Egypt
}

Correspondence should be addressed to Marwa Khairy; marwakhairy79@hotmail.com

Received 13 January 2014; Accepted 3 March 2014; Published 3 April 2014

Academic Editor: Carlos E. P. Corbett

Copyright (C) 2014 Rabab Fouad et al. This is an open access article distributed under the Creative Commons Attribution License, which permits unrestricted use, distribution, and reproduction in any medium, provided the original work is properly cited.

Background and Aim. Bacterial meningitis is a lethal, disabling endemic disease needing prompt antibiotic management. Gram stained smears is rapid accurate method for diagnosis of bacterial meningitis. In cases of negative gram stained smears diagnosis is delayed till culture results. We aim to assess the role of clinical presentations and routine CSF analysis in the cost-effective rapid diagnosis of negative gram stained smears bacterial meningitis. Methods. Cross sectional study including 623 acute meningitis patients divided into two groups: bacterial meningitis and nonbacterial meningitis groups. The clinical presentations, systemic inflammatory parameters, and CSF analysis were evaluated and compared in both groups. Results. Altered conscious level, localizing neurological signs, Kernig's and Brudzinski's signs together with peripheral leucocytosis $\left(>10.000 / \mathrm{mm}^{3}\right)$, high CRP $(>6)$ together with high CSF protein $(>50 \mathrm{gl} / \mathrm{dL})$, CSF neutrophilic count ( $\geq 50 \%$ of total CSF leucocytic count), and low CSF glucose level $(<45 \mathrm{gm} / \mathrm{dL})$ and CSF/serum glucose $\leq 0.6$ were significantly diagnostic in bacterial meningitis patients. From the significant CSF analysis variables CSF protein carried the higher accuracy of diagnosis $78 \%$ with sensitivity $88 \%$ and specificity $72 \%$. Conclusions. High CSF protein $(>50 \mathrm{mg} / \mathrm{dL})$ together with plasma inflammatory markers and CSF cytochemical parameters can diagnose bacterial meningitis in gram stain negative smear till culture results.

\section{Introduction}

Acute bacterial meningitis is a major cause of death and disability worldwide. It affects over one million people yearly, with higher incidence among developing countries and in specific geographic areas [1].

Meningitisis an endemic disease in Egypt; S. pneumonia meningitis is currently the leading cause of meningitis in Egypt and has the highest mortality rates among meningitis cases especially in patients less than one year of age $[2,3]$.

Acute meningitis is caused by a variety of infectious agents. The most serious form is caused by pyogenic bacteria, such as S. pneumoniae, N. meningitidis, and H. influenzae [4]. Viruses are the most common cause of aseptic meningitis, primarily enteroviruses, together with numerous nonviral and noninfectious etiologies [5].

Differentiating bacterial from nonbacterial meningitis is very important in deciding treatment. Bacterial meningitis is a life-threatening neurological condition and needs prompt parenteral antibiotics, compared to viral and aseptic meningitis which carries relatively better outcome [6]. Delay in the start of proper therapy introduces the potential for increased morbidity and mortality, if the patient does indeed have acute bacterial meningitis [5].

CSF culture is highly specific but lacks sensitivity, especially when antimicrobials have been given as well as the time needed till results appear [7]. Someinvestigators document bacterial meningitis only in patients with positive CSF culture 
and/or positive latex agglutination test on CSF or positive blood culture with concomitant CSF pleocytosis $[8,9]$.

Gram stain smears of the CSF permits a rapid, accurate method of diagnosis of bacterial meningitis in $60 \%-90 \%$ of patients; the percentage correlates with the CSF concentration of bacteria [10]. In case of negative gram stained smear the differentiation between bacterial and nonbacterial meningitis is needed with other tools [11].

Identification of the causative agent by Gram staining unfortunately shows low rate and variability in sensitivity [12]. The yield of bacteria detection depends on several factors as the number of organisms present, prior use of antibiotics, and technique used for smear preparation $[3,13]$.

The classic CSF abnormalities in bacterial meningitis are a polymorphonuclear leukocytosis, decreased glucose concentration, and increased protein concentration. In viral meningitis, the classic CSF abnormalities are a lymphocytic pleocytosis, a normal glucose concentration, and a normal or slightly elevated protein concentration [14].

In sterile CSF after antibiotic intake in case bacterial meningitis white cells found in CSF are primarily polymorphs, meningitis is bacterial in origin, which may persist throughout the illness $[15,16]$.

Additional diagnostic tests are necessary to distinguish between bacterial and viral meningitis. The peripheral WBC count, CRP, and ESR are usually elevated in patients with bacterial meningitis [17].

\section{Objectives}

The aim of our study is to assess the role of clinical presentations, serum inflammatory markers including CRP, and routine CSF analysis in the rapid diagnosis of acute bacterial meningitis in cases of negative gram stained smears to reach a cost-effective diagnostic approach based on routine diagnostic labs.

\section{Material and Methods}

3.1. Selection of Patients. Three-year period (2009-2012) prospective cross-sectional study was done including 623 patients diagnosed as acute meningitis presented to Shebin El-Kom Fever Hospital, a tertiary care center specialized in endemic diseases and infectious diseases especially meningitis and encephalitis.

Patients were subjected to thorough history taking and clinical examination with special emphasis on symptoms of meningeal irritation: fever, headache, vomiting, photophobia, and irritability. Signs of meningeal irritation as neck rigidity, Kernig sign, Brudzinski sign, altered conscious level, seizures, focal neurological signs, skin rash were assessed. In infants symptoms of weak suckling and high pitched crying and bulging anterior fontanel were reviewed in addition. The clinical assessment was conducted by two specialized clinicians together in the same setting of the diagnosis.

Special concern was conducted on the associated infections and previous antibiotic intake and antecedent illness as pneumonia, otitis media, sinusitis, urinary tract infection, and diarrhea or previous surgical intervention.

Laboratory tests included complete blood count (CBC), C-reactive protein (CRP), and serum blood glucose. CSF analysis was done including total white cells count (neutrophils or lymphocytes), protein and glucose level, and CSF/serum glucose. CSF was subjected to gram stain and cultures which were inoculated onto chocolate, blood, and MacConkey agars. Ziehl Neelsen stain for mycobacteria tuberculosis and India ink preparation were done when tuberculosis meningitis and cryptococcal meningitis were clinically suspected, respectively. The laboratory tests were all done by expert clinical pathologist and equipments were calibrated to overcome bias.

3.2. Patients' Classification. Total of 623 patients studied there were classified into two groups:

(1) Group I ( $n=457$ patients): bacterial meningitis with positive CSF culture or positive blood culture with concurrent meningitis,

(2) Group II ( $n=166$ patients): nonbacterial meningitis with CSF and negative blood cultures.

3.3. Patients Consent. Informed written consent from each patient and local ethical committee approval were obtained before starting the data collection. With respect to patients' confidentiality, patients were represented in the study by code numbers. All personal data was concealed. The study protocol conformed to the ethical guidelines of the 1975 Declaration of Helsinki as reflected in a prior approval by the institution's human research committee.

3.4. Statistical Analysis. Data were collected and statistically analyzed using SPSS version 11 statistical package. Comparison of qualitative data was performed with chi-square $\left(\chi^{2}\right)$ test. Multivariate backwards stepwise binary logistic regression analysis with bacterial meningitis-as the dependent factor-was done. The validity of screening tests was measured and expressed as sensitivity, specificity, accuracy, positive predictive value, and negative predictive value (in comparison to diagnostic tests). $P$ value $<0.05$ was considered significant.

Spearman correlation coefficient test was used for correlation between nonparametric quantitative data. Also, MannWhitney $U$ test was used for comparison between nonparametric quantitative data between two groups.

\section{Results}

Among the studied 623 patients, bacterial meningitis represented $73.3 \%$ (457 patients) compared to $26.7 \%$ (166 patients) nonbacterial meningitis of the studied population. Bacterial meningitis carried a higher mortality rate $20.6 \%$ than nonbacterial meningitis being only $3.6 \%$.

Among the bacterial meningitis patients, the isolated organisms on the CSF bacterial cultures (chocolate, blood, and MacConkey agar) S. pneumoniae was the most frequently 
TABLE 1: Demographic data of bacterial and nonbacterial meningitis in the studied population.

\begin{tabular}{|c|c|c|c|c|c|}
\hline \multirow{2}{*}{ Demographic data } & \multicolumn{2}{|c|}{ Group I $(n=457)$} & \multicolumn{2}{|c|}{ Group II $(n=166)$} & \multirow{2}{*}{$P$ value } \\
\hline & Number & $\%$ & Number & $\%$ & \\
\hline \multicolumn{6}{|l|}{ Age } \\
\hline 0-1 month & $7^{*}$ & $1.5^{*}$ & $0^{\dagger}$ & $0.0^{\dagger}$ & \multirow{5}{*}{0.07} \\
\hline$>1$ month -6 years & 172 & 37.6 & 66 & 39.7 & \\
\hline$>6-18$ years & 74 & 16.2 & 24 & 14.4 & \\
\hline$>18-60$ years & 172 & 37.6 & 62 & 37.3 & \\
\hline$>60$ years & $32^{*}$ & $7.0^{*}$ & $14^{\dagger}$ & $8.4^{\dagger}$ & \\
\hline$P$ & \multicolumn{2}{|c|}{$<0.01^{*}$} & \multicolumn{2}{|c|}{$<0.01^{\dagger}$} & \\
\hline \multicolumn{6}{|l|}{ Sex } \\
\hline Male & 279 & 61.00 & 95 & 57.2 & \multirow{2}{*}{0.08} \\
\hline Female & 179 & 39.00 & 71 & 42.8 & \\
\hline$P$ & \multicolumn{2}{|c|}{$<0.01$} & \multicolumn{2}{|c|}{$<0.01$} & \\
\hline
\end{tabular}

isolated (52\%) while N. meningitidis in $22.2 \%$ and H. influenzae in $14.8 \%$.

4.1. Demographic Data of the Studied Patients. Patients with either bacterial or nonbacterial meningitis obeyed the same demographic features; that is, patients were distributed in all age groups, with low rates of occurrence in the extremes of age (the neonates and above 60 years). Men were affected more significantly than female patients as presented in Table 1.

4.2. Clinical Presentations of the Studied Patients. Antecedent illnesses (i.e., diseases diagnosed at the time or shortly before the diagnosis of meningitis) were recorded in $34 \%$ of the total patients with pneumonia recorded in $18.8 \%$ of the cases. Diarrhea, otitis media, and sinusitis were reported to a lesser degree. All cases of recurrent meningitis were due to posttraumatic CSF leak and mainly of bacterial meningitis origin (22 out of 24 patients). A significant proportion of meningitis patients (55.2\%) reported a positive history of antibiotic intake in the few days (up to 72 hours) before admission to the hospital (Table 2).

Clinical presentations (e.g., fever, vomiting, and blurring of vision) were of little assistance in differentiating bacterial from nonbacterial meningitis, while signs of meningeal irritation as Kernig's sign, Brudzinski's sign, and altered conscious level and localizing neurological signs were found to be significantly higher in bacterial than nonbacterial meningitis group as shown in Table 3.

4.3. Diagnosis of Meningitis in the Studied Patients. The plasma inflammatory markers showed highly significant difference between both groups $(P$ value $<0.01)$. Leucocytosis $\left(>10,000 / \mathrm{mm}^{3}\right)$ was encountered in bacterial meningitis in $47.9 \%$ of patients, while only in $24.1 \%$ of patients with nonbacterial meningitis. Positive CRP result $(\geq 6)$ was significantly higher in patients with bacterial $(47.9 \%)$ than nonbacterial meningitis (15.7\%) as shown in Table 4.

The CSF analysis of the studied patients also showed significant difference between the two groups of patients.
Elevated CSF protein ( $>50 \mathrm{mg} / \mathrm{dL}$ ) was present in $87.4 \%$ of patients with bacterial meningitis versus $47.6 \%$ of patients with nonbacterial meningitis. Decreased CSF glucose values ( $<45 \mathrm{mg} / \mathrm{dL}$ ) were found in $46.8 \%$ and $15.7 \%$ of patients with bacterial and nonbacterial meningitis, respectively.

In patients with bacterial meningitis, $67.4 \%$ had a CSF leukocyte count in the range of $>100-1,000 \mathrm{cell} / \mathrm{mm}^{3}$ and $32.6 \%$ had a leukocyte count $>1,000$ cell $/ \mathrm{mm}^{3}$. Patients with bacterial meningitis had a predominantly neutrophilic CSF, that is, neutrophil percentage $>50 \%(69.4 \%)$. On the other hand, patients with nonbacterial meningitis had a predominantly lymphocytic CSF in $76.5 \%$ of cases as in Table 5.

$\mathrm{CSF} /$ serum glucose ratios were calculated; $90.6 \%$ and $64.5 \%$ of patients with bacterial and nonbacterial meningitis were found to have a decreased ratio (CSF/serum glucose $<0.6)$, respectively.

The multivariate binary logistic regression analysis was performed for the significant variables including peripheral leucocytosis, high CRP, and CSF analysis. Validation of the serum inflammatory parameters and the CSF analysis, sensitivity, specificity, accuracy, positive predictive value (PPV), and negative predictive value (NPV) were calculated in Table 6. Three parameters, CSF protein, neutrophil count, and CRP, appeared to have good predictive value in bacterial meningitis. On the other hand CSF glucose and peripheral blood leukocytosis appeared to be less efficient in the diagnosis. ROC curve was plotted with CSF protein having the best performing curve for diagnosing of bacterial meningitis with sensitivity of $88 \%$, specificity of $72 \%$, accuracy of $78 \%$, positive predictive value of $84 \%$, and negative predictive value of $60 \%$.

\section{Discussion}

Meningitis is an endemic disease in Egypt, with a higher reported incidence of bacterial meningitis ranging from $47 \%$ to $68 \%[2,18,19]$. Bacterial meningitis can be lethal if not diagnosed or treated at an early stage. Usually Viral meningitis in immunocomptent and aseptic meningitis carries a good 
TABLE 2: Underlying and associated conditions in bacterial and nonbacterial meningitis groups in the studied population.

\begin{tabular}{|c|c|c|c|c|c|c|c|}
\hline \multirow{2}{*}{ Clinical manifestations } & \multicolumn{2}{|c|}{ Group I $(N=457)$} & \multicolumn{2}{|c|}{ Group II $(N=166)$} & \multicolumn{2}{|c|}{ Total $(N=623)$} & \multirow{2}{*}{$P$} \\
\hline & Number & $\%$ & Number & $\%$ & Number & $\%$ & \\
\hline Fever & 401 & 87.8 & 144 & 86.7 & 545 & 87.5 & 0.8 \\
\hline Headache & 370 & 81.1 & 131 & 78.9 & 360 & 80.5 & 0.4 \\
\hline Vomiting & 222 & 48.6 & 71 & 42.8 & 293 & 47 & 0.9 \\
\hline Irritability & 134 & 29.3 & 43 & 25.9 & 177 & 28.4 & 0.3 \\
\hline Photophobia & 42 & 9.2 & 15 & 9.00 & 57 & 9.1 & 0.5 \\
\hline Neck rigidity & 328 & 71.8 & 107 & 64.5 & 3.09 & 69.8 & 0.5 \\
\hline Kernig's sign & 187 & 40.9 & 54 & 32.5 & 241 & 38.7 & 0.03 \\
\hline Brudzinski’s sign & 193 & 42.2 & 52 & 31.3 & 245 & 39.3 & $<0.01$ \\
\hline Skin rash & 20 & 4.4 & 3 & 1.8 & 23 & 3.7 & 0.08 \\
\hline Altered conscious level & 205 & 44.9 & 46 & 27.7 & 251 & 40.2 & $<0.01$ \\
\hline Seizures & 107 & 23.4 & 38 & 22.9 & 145 & 23.2 & 0.07 \\
\hline Localizing signs & 25 & 5.5 & 3 & 1.8 & 28 & 4.5 & $<0.05$ \\
\hline Anterior fontanel bulge & $57 / 123$ & 47.1 & $20 / 46$ & 43.5 & $77 / 169$ & 45.5 & 0.5 \\
\hline Abnormal crying & $54 / 123$ & 36.6 & $16 / 46$ & 34.8 & $70 / 169$ & 41.4 & 0.3 \\
\hline Weak suckling & $43 / 123$ & 35.00 & $16 / 46$ & 34.8 & $59 / 169$ & 35 & 0.5 \\
\hline
\end{tabular}

TABLE 3: Clinical manifestations of bacterial and aseptic meningitis in the studied population.

\begin{tabular}{|c|c|c|c|c|c|c|c|}
\hline \multirow{2}{*}{ Condition } & \multicolumn{2}{|c|}{ Group I $(N=457)$} & \multicolumn{2}{|c|}{ Group II $(N=166)$} & \multicolumn{2}{|c|}{ Total $(N=623)$} & \multirow{2}{*}{$P$} \\
\hline & Number & $\%$ & Number & $\%$ & Number & $\%$ & \\
\hline Pneumonia & 79 & $17.3^{*}$ & 38 & $22.9^{*}$ & 117 & $18.8^{*}$ & \\
\hline Recurrent meningitis & 22 & 4.8 & 2 & 1.2 & 24 & 3.9 & \\
\hline Diarrhea & 12 & 2.6 & 12 & 7.2 & 24 & 3.8 & \\
\hline Otitis media & 19 & 4.2 & 2 & 1.2 & 21 & 3.4 & \\
\hline Sinusitis & 15 & 3.3 & 3 & 1.8 & 18 & 2.9 & \\
\hline Urinary tract infection & 0 & 0 & 6 & 3.6 & 6 & 1.0 & \\
\hline Cirrhosis & 3 & 0.7 & 0 & 0 & 3 & 0.5 & \\
\hline Spinal anesthesia & 0 & 0 & 1 & 0.6 & 1 & 0.2 & \\
\hline Total & 150 & 33 & 64 & 38 & 214 & 34 & $<0.01^{*}$ \\
\hline \multicolumn{8}{|l|}{ Antibiotic intake } \\
\hline Positive & 275 & 60.2 & 69 & 41.6 & 344 & 55.2 & \multirow{2}{*}{$<0.01$} \\
\hline Negative & 182 & 39.8 & 97 & 58.4 & 279 & 44.8 & \\
\hline
\end{tabular}

${ }^{*} P$ value significant with these values.

TABLE 4: Plasma inflammatory markers inbacterial and nonbacterial meningitis groups in the studied population.

\begin{tabular}{|c|c|c|c|c|c|}
\hline \multirow{2}{*}{ Inflammatory markers } & \multicolumn{2}{|c|}{ Group I $(n=457)$} & \multicolumn{2}{|c|}{ Group II $(n=166)$} & \multirow{2}{*}{$P$ value } \\
\hline & Numbe & $\%$ & Numbe & $\%$ & \\
\hline \multicolumn{6}{|l|}{ WBCs $\left(/ \mathrm{mm}^{3}\right)$} \\
\hline $4.000-10.000($ mean $\pm S D)$ & \multicolumn{2}{|c|}{$10877.02 \pm 5113.76$} & \multicolumn{2}{|c|}{$8093.37 \pm 4488.99$} & $<0.01$ \\
\hline$\leq 10.000$ & 238 & 52.1 & 126 & 75.9 & $<0.01$ \\
\hline$>10.000$ & 219 & 47.9 & 40 & 24.1 & $<0.01$ \\
\hline \multicolumn{6}{|l|}{ CRP (mg/L) } \\
\hline Normal $(<6)($ mean \pm SD $)$ & \multicolumn{2}{|c|}{$27.03 \pm 28.07$} & \multicolumn{2}{|c|}{$4.24 \pm 0.11$} & 0.01 \\
\hline Positive $(>6)$ & 340 & 74.4 & 26 & 15.7 & $<001$ \\
\hline Negative $(<6)$ & 117 & 25.6 & 140 & 84.3 & $<0.01$ \\
\hline
\end{tabular}

WBCs: white blood cells; CRP: C-reactive protein. 
TABLE 5: CSF parametersmarkers inbacterial and aseptic meningitis groups in the studied population.

\begin{tabular}{|c|c|c|c|c|c|}
\hline \multirow{2}{*}{ CSF parameters } & \multicolumn{2}{|c|}{ Group I $(n=457)$} & \multicolumn{2}{|c|}{ Group II $(n=166)$} & \multirow{2}{*}{$P$} \\
\hline & Number & $\%$ & Number & $\%$ & \\
\hline \multicolumn{6}{|l|}{ Protein $(\mathrm{mg} / \mathrm{dL})$} \\
\hline Mean \pm SD & \multicolumn{2}{|c|}{$135.89 \pm 86.98$} & \multicolumn{2}{|c|}{$56.66 \pm 24.53$} & 0.01 \\
\hline$<50$ & 57 & 12.5 & 87 & 52.4 & \multirow{2}{*}{$<0.01$} \\
\hline$>50$ & 400 & 87.5 & 79 & 47.6 & \\
\hline \multicolumn{6}{|l|}{ Glucose (mg/dL) } \\
\hline Mean \pm SD & \multicolumn{2}{|c|}{$48.30 \pm 28.78$} & \multicolumn{2}{|c|}{$63.96 \pm 28.50$} & 0.01 \\
\hline$>45$ & 243 & 53.2 & 140 & 84.3 & $<0,01$ \\
\hline$<45$ & 214 & 46.8 & 26 & 15.7 & \\
\hline \multicolumn{6}{|c|}{$\mathrm{CSF} /$ serum glucose } \\
\hline$>0.6$ & 43 & 9.4 & 59 & 35.5 & \multirow{2}{*}{$<0.01$} \\
\hline$\leq 0.6$ & 414 & 90.6 & 107 & 64.5 & \\
\hline \multicolumn{6}{|c|}{ WBCs (total $/ \mathrm{mm}^{3}$ ) } \\
\hline Mean \pm SD & \multicolumn{2}{|c|}{$3484.65 \pm 10186.54$} & \multicolumn{2}{|c|}{$66.80 \pm 23.45$} & 0.01 \\
\hline$\leq 100$ & 0 & 0 & 166 & 100 & \\
\hline$>100-1000$ & 308 & 67.4 & 0 & 0 & $<0.01$ \\
\hline$>1000$ & 149 & 32.6 & 0 & 0 & \\
\hline \multicolumn{6}{|l|}{ Neutrophil \% } \\
\hline Mean \pm SD & \multicolumn{2}{|c|}{$61.65 \pm 26.69$} & \multicolumn{2}{|c|}{$29.45 \pm 27.65$} & 0.01 \\
\hline$>50$ & 317 & 69.4 & 39 & 23.5 & $<0.01$ \\
\hline$\leq 50$ & 140 & 30.6 & 127 & 76.5 & \\
\hline
\end{tabular}

TABLE 6: Validation of CSF and blood parameters in detecting bacterial meningitis.

\begin{tabular}{lccccc}
\hline Parameters & Sensitivity (\%) & Specificity $(\%)$ & Accuracy (\%) & PPV (\%) & NPV (\%) \\
\hline CSF protein & $\mathbf{8 8}$ & $\mathbf{5 2}$ & $\mathbf{7 8}$ & $\mathbf{8 4}$ & $\mathbf{6 0}$ \\
CSF glucose & 47 & 84 & 57 & 71 & 89 \\
CSF neutrophil & 69 & 77 & 77 & 48 & 53 \\
Serum CRP & 74 & 84 & 55 & 54 \\
Peripheral WBC & 48 & 76 & & 35 \\
\hline
\end{tabular}

PPV: positive predictive value; NPV: negative predictive value.

prognosis and get cured within one or two weeks without any treatment $[20,21]$.

It is evident that the clinical differentiation between bacterial and aseptic meningitis is challenging. Rapid diagnosis and treatment of acute community-acquired bacterial meningitis reduces mortality and neurological sequelae but can be delayed by atypical presentation, assessment of lumbar puncture safety, and poor sensitivity of standard diagnostic microbiology [22].

In endemic areas for bacterial meningitis as Egypt, such a serious disease with poor outcome in a relatively low resources setting and in an easy and rapid noncomplicating, cost affordable way of diagnosis based on routine diagnostic labs is important.

The aim of our study is to assess the role of clinical presentations, serum inflammatory markers including CRP, and routine CSF analysis in the rapid diagnosis of acute bacterial meningitis in cases of negative gram stained smears to start rapid treatment as early as possible without waiting culture results available in suspected cases of bacterial meningitis to overcome the lethal complications. Our study focused on the validation of clinical and routine diagnostic tests in bacterial meningitis and detection of the most discriminating factors with respect to nonbacterial meningitis.

In the current study, bacterial meningitis represents $73.3 \%$ of the studied population and nonbacterial meningitis accounted for the remaining $26.7 \%$. The ratio of bacterial to aseptic meningitis cases differed between several studies $[20,23]$. This difference can be attributed to differences in the place and time of studies and implementation of anticapsular vaccines [24].

In our study, meningitis in the preschool children represented $39.3 \%$ of the studied population. Other studies documented a higher prevalence up to $60-75 \%[25,26]$. The decline of rate of occurrence may be explained by the availability of effective vaccines against common pathogens (e.g., capsulated organisms) [27, 28].

The low incidence of meningitis in the extremes of ages does not allow the conclusion that younger/older patients are indeed less affected by bacterial meningitis; it may also mean that the group of patients with bacterial meningitis at the extremes of age are underrepresented in this study. 
The dominating causative agent for bacterial meningitis has changed over the years in Egypt [29]. S. pneumoniae represents $52 \%$ of the isolated organisms in our patients with antecedent pneumonia in $17.3 \%$ of bacterial meningitis cases. Pneumococcal meningitis is currently the leading cause of meningitis in Egyptdue to decrease in the incidence of meningococcal diseasereflecting the increased use of polysaccharide meningococcal vaccines. Similar pneumococcal predominance especially serotype 1 was recently noted at the African meningitis belt.

In our study, the triad of meningeal inflammation, that is fever, headache, and neck rigidity, was found in $87.5 \%$, $80.5 \%$, and $69.8 \%$, respectively, with no significant difference between the two groups. Similar rates were reported by several investigators [3, 28, 30]. Kernig's and Brudzinski's signs were statistically significant in our bacterial meningitis patients. However, previous study noted that Brudzinski's sign and nuchal rigidity did not accurately discriminate between patients with meningitis, even bacterial meningitis, and patients without meningitis [31].

Altered level of consciousness and localizing neurologic signs were more significant in bacterial $(44.9 \%$ and $5.5 \%$, resp.) than nonbacterial meningitis patients $(27.7 \%$ and $1.8 \%$, resp.). These neurologic manifestations are related to the severity of the disease and the time interval before arrival to the hospital [23]. As previously reported, focal neurologic deficits and seizure activity do not commonly occur in aseptic meningitis [14].

Although around half of the studied patients (55\%) were preexposed to antibiotics, this may not affect the diagnosis of bacterial meningitis as the duration of use of antibiotics was within 72 hours of the diagnosis. The leucocytic count and inflammatory markers of CSF remain positive even in sterile CSF after the use of antibiotics [32].

Considerable peripheral leucocytosis $\left(>10.000 / \mathrm{mm}^{3}\right)$ and raised CRP level $(>6)$ was significantly higher in our bacterial meningitis group in $52.1 \%$ and $74.4 \%$ of patients, respectively. It is reported that plasma inflammatory markers such as peripheral blood leukocyte count and CRP can be very useful in discriminating between bacterial and nonbacterial meningitis $[6,28]$.

Meta-analysis from 35 studies proposed to use CRP as an additional tool for discriminating bacterial meningitis from viral meningitis, without having evaluated its independent contribution relative to other parameters such as white blood cell count, CSF white cell count, protein, or glucose [17].

Our bacterial meningitis patients showed significant CSF leucocytosis with neutrophilic predominance (69\%) and high CSF protein $(>50 \mathrm{mg} / \mathrm{dL})(87.5 \%)$ compared to the nonbacterial meningitis group, $23.5 \%$ and $47.7 \%$, respectively. In bacterial meningitis, CSF leukocyte count $<1,000 /$ uL may be found early in the disease, in partially treated bacterial meningitis, in overwhelming bacterial meningitis, and in immune-suppressed and leucopenic patients [16-18].

CSF glucose concentration is decreased $<45 \mathrm{mg} / \mathrm{dL}$ in $46.8 \%$ of patients with bacterial meningitis and significantly above $45 \mathrm{mg} / \mathrm{dL}$ in $84.3 \%$ of the aseptic meningitis patients. CSF glucose is typically normal in aseptic meningitis, although it may be decreased in cases due to enteroviruses, HSV-2, and VZV meningitis [14].

Previous study showed that CSF to serum glucose of $\leq 0.4$ was $80 \%$ sensitive and $98 \%$ specific for the diagnosis of bacterial meningitis in children below 2 months and at a value below or equal to 0.6 in the neonates [16]. In our study, $90.6 \%$ of the bacterial meningitis patients CSF/glucose level was $<0.6$.

Validation of the significant parameters in the CSF analysis showed that CSF protein concentration was of the highest sensitivity, specificity, and accuracy in diagnosis of bacterial meningitis in our study. Many studies reported the same finding with variation in the mean values between bacterial and aseptic meningitis patients $[13,28]$.

We conclude that for rapid diagnosis of bacterial meningitis in cases of negative gram stained smears the combination of high CSF protein content ( $>50 \mathrm{mg} / \mathrm{dL}$ ) together with the signs of meningeal irritation, localizing signs, and cytochemical CSF analyses can expect bacterial meningitis in these cases till culture results appearance. The classic biological markers in blood in the form of high CRP and peripheral leucocytosis can increase the sensitivity of diagnosis without adding high cost compared to CSF culture and smears which are of low diagnostic yield.

PCR and agglutination tests were not used in the study which is considered as limitation of the study. However, the PCR is costly and the study is aiming to find a relatively cheap and accurate method of diagnosis in a set of large number of patients in an endemic area of the disease. The rapid tests in previous studies, although having good sensitivity, lack specificity, were not conclusive, and did not show a high sensitivity or specificity [6]. Nevertheless, the routine use of latex agglutination for the etiologic diagnosis of bacterial meningitis has recently been questioned [16].

We could not conclude that the negative parameters are not a rationale for exclusion of diagnosis of bacterial meningitis and it would be hard to justify not treating patients in the first hours of diagnosis with antibiotics or to suggest a nonbacterial etiology. Further studies are needed to reach this conclusion.

\section{Conflict of Interests}

The authors declare that there is no conflict of interests regarding the publication of this paper.

\section{Acknowledgment}

The authors acknowledge Shebin El-Kom Fever Hospital, Egyptian Ministry of Health, for the work support.

\section{References}

[1] L. Agier, H. Broutin, E. Bertherat et al., "Timely detection of bacterial meningitis epidemics at district level: a study in three countries of the African Meningitis Belt," Transactions of the Royal Society of Tropical Medicine and Hygiene, vol. 107, no. 1, pp. 30-36, 2013. 
[2] H. F. M. Farag, M. M. Abdel-Fattah, and A. M. Youssri, "Epidemiological, clinical and prognostic profile of acute bacterial meningitis among children in Alexandria, Egypt," Indian Journal of Medical Microbiology, vol. 23, no. 2, pp. 95-101, 2005.

[3] S. Afifi, M. O. Wasfy, M. A. Azab et al., "Laboratory-based surveillance of patients with bacterial meningitis in Egypt (1998-2004)," European Journal of Clinical Microbiology and Infectious Diseases, vol. 26, no. 5, pp. 331-340, 2007.

[4] K. S. Adriani, D. van de Beek, M. C. Brouwer, L. Spanjaard, and J. de Gans, "Community-acquired recurrent bacterial meningitis in adults," Clinical Infectious Diseases, vol. 45, no. 5, pp. e46-e51, 2007.

[5] A. R. Tunkel and W. M. Scheld, "Acute meningitis", in Principles and Practice of Infectious Disease, G. L. Mandell, J. E. Bennett, and R. Dolin, Eds., chapter 80, pp. 1083-1119, Churchill Livingstone/Elsevier, 6th edition, 2005.

[6] P. Ray, G. Badarou-Acossi, A. Viallon et al., "Accuracy of the cerebrospinal fluid results to differentiate bacterial from nonbacterial meningitis, in case of negative gram-stained smear," The American Journal of Emergency Medicine, vol. 25, no. 2, pp. 179-184, 2007.

[7] L. E. Nigrovic, R. Malley, C. G. Macias et al., "Effect of antibiotic pretreatment on cerebrospinal fluid profiles of children with bacterial meningitis," Pediatrics, vol. 122, no. 4, pp. 726-730, 2008.

[8] N. Begum, I. Ahmed, M. A. Salam, S. Begum, and K. M. F. Alam, "Role of latex particle agglutination test in the diagnosis of meningitis," Bangladesh Journal of Medical Microbiology, vol. 1, no. 1, pp. 10-12, 2007.

[9] F. Dubos, B. Korczowski, D. A. Aygun et al., "Distinguishing between bacterial and aseptic meningitis in children: European comparison of two clinical decision rules," Archives of Disease in Childhood, vol. 95, no. 12, pp. 963-967, 2010.

[10] A. R. Tunkel, Bacterial Meningitis, Lippincott Williams \& Wilkins, Philadelphia, 2001.

[11] L. Simon, F. Gauvin, D. K. Amre, P. Saint-Louis, and J. Lacroix, "Serum procalcitonin and C-reactive protein levels as markers of bacterial infection: a systematic review and meta-analysis," Clinical Infectious Diseases, vol. 39, no. 2, pp. 206-217, 2004.

[12] R. C. Parmar, S. Warke, P. Sira, and J. R. Kamat, "Rapid diagnosis of meningitis using reagent strips," Indian Journal of Medical Sciences, vol. 58, no. 2, pp. 62-66, 2004.

[13] R. Mani, S. Pradhan, S. Nagarathna, R. Wasiulla, and A. Chandramuki, "Bacteriological profile of community acquired acute bacterial meningitis: a ten-year retrospective study in a tertiary neurocare centre in South India," Indian Journal of Medical Microbiology, vol. 25, no. 2, pp. 108-114, 2007.

[14] K. L. Roos, "Cerebrospinal fluid," in Principles of Neurologic Infectious Diseases, K. L. Roos, Ed., chapter 1, pp. 1-12, McGrawHill, 2003.

[15] B. Negrini, K. J. Kelleher, and E. R. Wald, "Cerebrospinal fluid findings in aseptic versus bacterial meningitis," Pediatrics, vol. 105, no. 2, pp. 316-319, 2000.

[16] A. R. Tunkel, B. J. Hartman, S. L. Kaplan et al., "Practice guidelines for the management of bacterial meningitis," Clinical Infectious Diseases, vol. 39, no. 9, pp. 1267-1284, 2004.

[17] L. U. Gerdes, P. E. Jørgensen, E. Nexø, and P. Wang, "C-reactive protein and bacterial meningitis: a meta-analysis," Scandinavian Journal of Clinical \& Laboratory Investigation, vol. 58, no. 5, pp. 383-394, 1998.
[18] H. Peltola, "Burden of meningitis and other severe bacterial infections of children in Africa: implications for prevention," Clinical Infectious Diseases, vol. 32, no. 1, pp. 64-75, 2001.

[19] F. G. Youssef, H. El-Sakka, A. Azab et al., "Etiology, antimicrobial susceptibility profiles, and mortality associated with bacterial meningitis among children in Egypt," Annals of Epidemiology, vol. 14, no. 1, pp. 44-48, 2004.

[20] S. Chanteau, S. Dartevelle, A. E. Mahamane, S. Djibo, P. Boisier, and F. Nato, "New rapid diagnostic tests for neisseria meningitidis serogroups A, W135, C, and Y," PLoS Medicine, vol. 3, no. 9, pp. 1579-1586, 2006.

[21] S. K. Dash, M. Sharma, S. Khare, and A. Kumar, "rmpM gene as a genetic marker for human bacterial meningitis," Cell and Molecular Biology, vol. 58, no. 1, pp. 26-30, 2012.

[22] M. C. Brouwer, G. E. Thwaites, A. R. Tunkel, and D. van de Beek, "Dilemmas in the diagnosis of acute community-acquired bacterial meningitis," The Lancet, vol. 380, no. 9854, pp. 16841692, 2012.

[23] G. Amarilyo, A. Alper, A. Ben-Tov, and G. Grisaru-Soen, "Diagnostic accuracy of clinical symptoms and signs in children with meningitis," Pediatric Emergency Care, vol. 27, no. 3, pp. 196-199, 2011.

[24] World Health Organization, Regional Office for Africa, "Standard operating procedures for enhanced meningitis surveillance in Africa," 2009, http://www.afro.who.int/index .php?option $=$ com_docman\&task=doc_download $\&$ gid $=4722$.

[25] D. Mihalache, V. Luca, I. Teodorescu et al., "Nosocomial staphylococcal meningitis," Revista Medico-Chirurgicala a Societatii de Medici si Naturalisti din Lasi, vol. 103, no. 3-4, pp. 167-171, 1999.

[26] S. Afifi, M. S. Karsany, M. Wasfy, G. Pimentel, A. Marfin, and R. Hajjeh, "Laboratory-based surveillance for patients with acute meningitis in sudan, 2004-2005," European Journal of Clinical Microbiology and Infectious Diseases, vol. 28, no. 5, pp. 429-435, 2009.

[27] A. Bechini, M. Levi, S. Boccalini et al., "Present situation and new perspectives for vaccination against Neisseria meningitidis in Tuscany, Central Italy," Journal of Preventive Medicine and Hygiene, vol. 53, no. 2, pp. 61-67, 2012.

[28] M. A. Dery and R. Hasbun, "Changing epidemiology of bacterial meningitis," Current Infectious Disease Reports, vol. 9, no. 4, pp. 301-307, 2007.

[29] D. van de Beek, J. de Gans, A. R. Tunkel, and E. F. M. Wijdicks, "Community-acquired bacterial meningitis in adults," New England Journal of Medicine, vol. 354, no. 1, pp. 44-53, 2006.

[30] D. Van De Beek, J. De Gans, A. R. Tunkel, and E. F. M. Wijdicks, "Community-acquired bacterial meningitis in adults," New England Journal of Medicine, vol. 354, no. 1, pp. 44-53, 2006.

[31] K. E. Thomas, R. Hasbun, J. Jekel, and V. J. Quagliarello, "The diagnostic accuracy of Kernig's sign, Brudzinski's sign, and nuchal rigidity in adults with suspected meningitis," Clinical Infectious Diseases, vol. 35, no. 1, pp. 46-52, 2002.

[32] J. E. Mueller, S. Yaro, M. S. Ouédraogo et al., "Pneumococci in the African meningitis belt: meningitis incidence and carriage prevalence in children and adults," PLoS ONE, vol. 7, no. 12, Article ID e52464, 2012. 


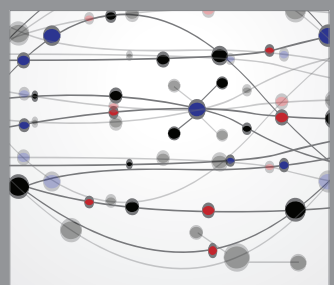

The Scientific World Journal
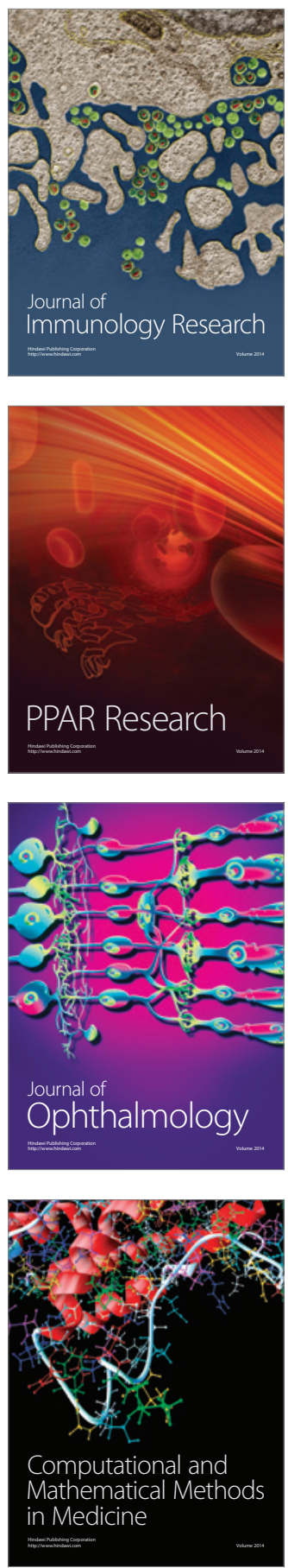

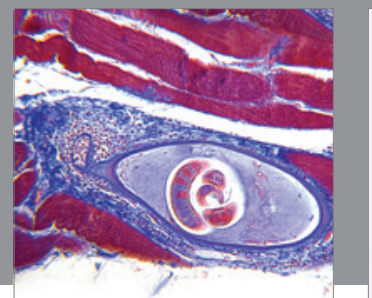

Gastroenterology

Research and Practice
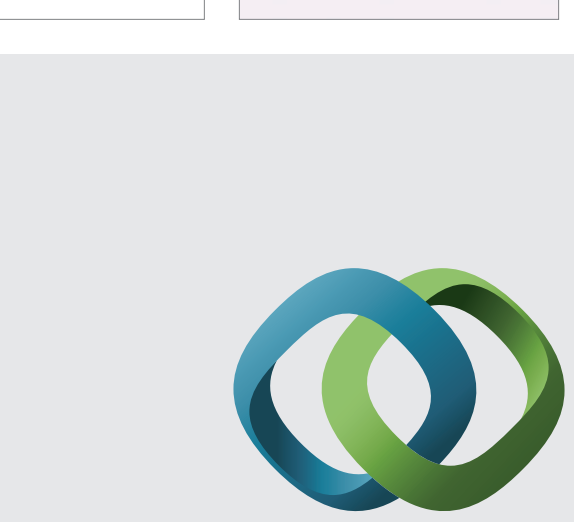

\section{Hindawi}

Submit your manuscripts at

http://www.hindawi.com
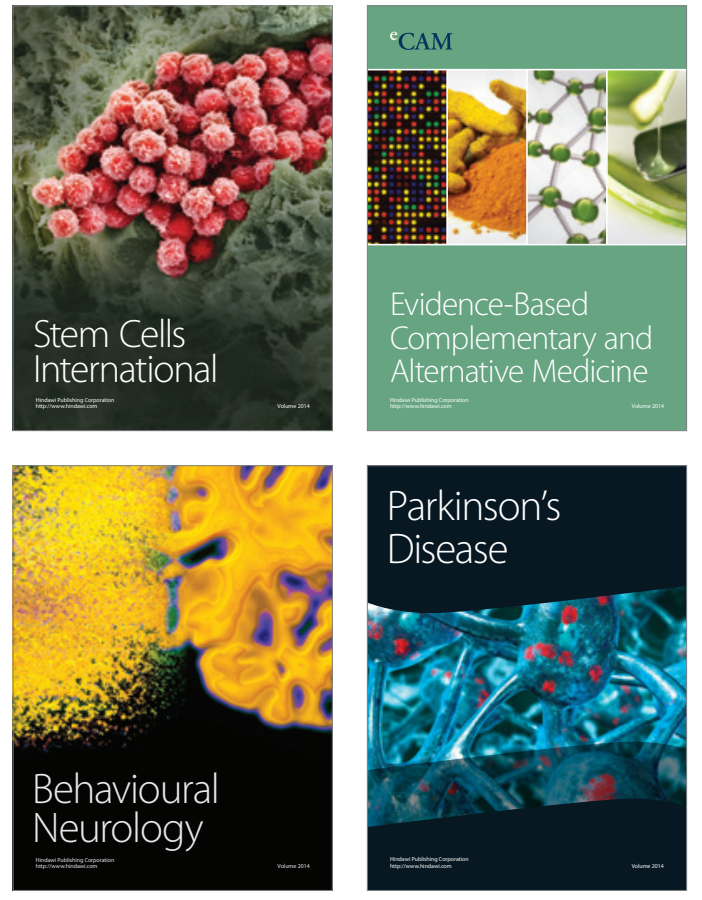
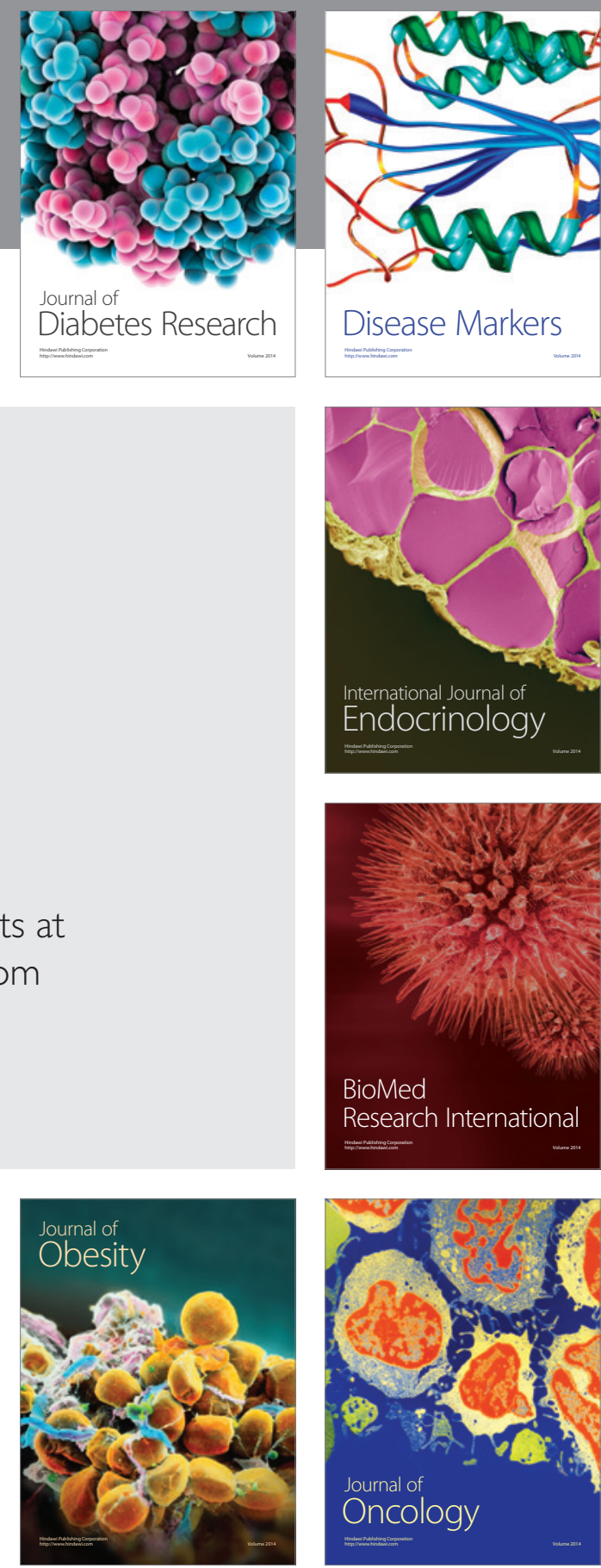

Disease Markers
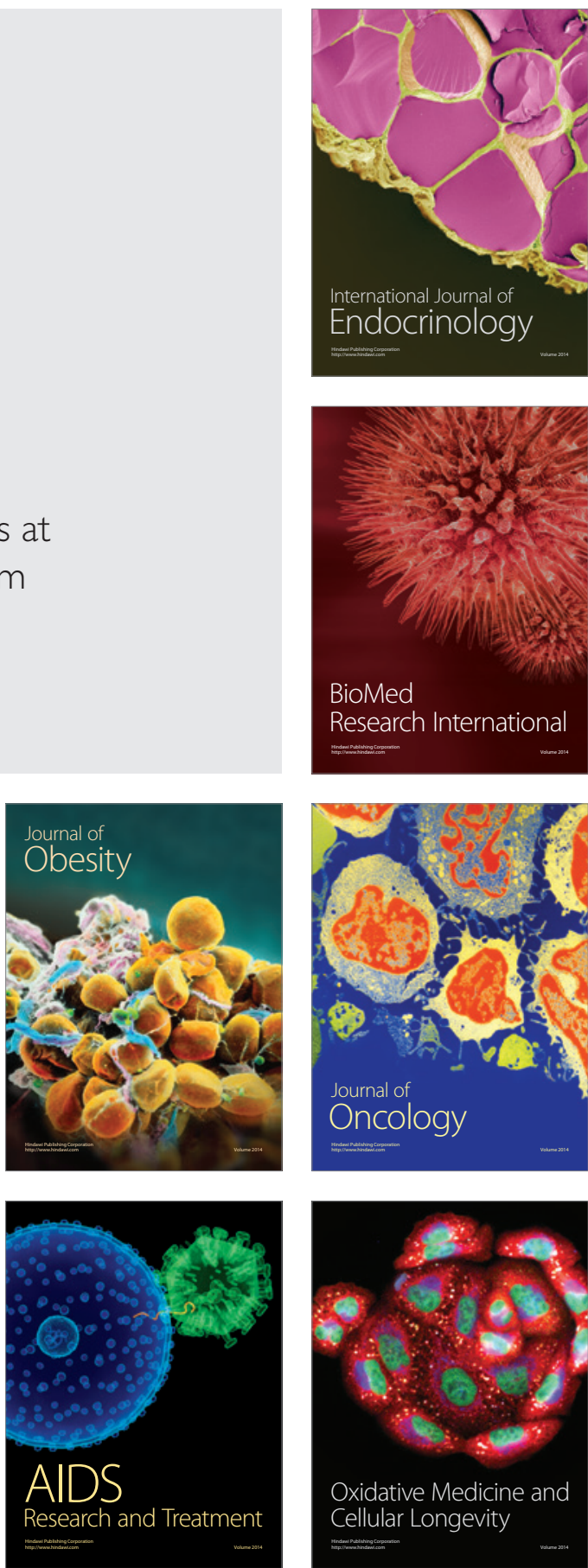